\title{
Kedudukan Wahyu dan Akal dalam Penghujahan berdasarkan Ilmu Mantik
}

Shahir Akram Hassan*

Pusat Kajian Pengurusan Pembangunan Islam (ISDEV), Universiti Sains Malaysia, Pulau Pinang, Malaysia

* Corresponding author: shahirakram@usm.my

\begin{abstract}
This article focuses on the discussion about the positions of the human mind and prophetic revelations in Islamic research. In the usual Social Science research, only the human mind serves as the basis for proofs and theory of knowledge (epistemology). The research would reject prophetic revelations. In Islam, however, there is a consensus that prophetic revelations must be placed as better proofs and theory of knowledge over the the human mind. As such, what are the positions of prophetic revelations and the human mind in Islamic research? To answer this question, logic is used as reference. Logic is the study of arguments based on human reasoning, as defined in Islam. Logic also serves as a method of determining the validity of proofs which can be used in an argument. The questions which arise then, are: What is the position of the human mind in Islamic research? What is the order of priority between the human mind and prophetic revelations in an Islamic research? To answer these questions, this paperwork will use literary research and textual analysis to analyse the positions of prophetic revelations and the human mind according to logic. This article will study the definitions of the human mind and prophetic revelation in Islam. Then the positions of the human mind and prophetic revelations will be analysed in a logical discussion, to serve as a method to be used in Islamic research. The use of logic is observed as having cleared the confusion in determining the positions of the human mind and prophetic revelations in Islamic research. How the prophetic revelations are used in Islamic research in accordance to the Islamic research method is also discussed. The results of this research found that logic approves of both the "naqli" and "aqli" proofs. The human mind is actually recognised as a legitimate instrument for proofs in Islam but it cannot take precedence over prophetic revelations. Instead, prophetic revelations serve an important role in Islamic research. However, certain methods must be followed when using the prophetic revelations in Islamic research in order for them to be valid.
\end{abstract}

Keywords: Islamic research methodology; reason (aql); revelation (wahyu); Al-Qur’an; logic

\begin{abstract}
Abstrak
Makalah ni tertumpu kepada perbincangan tentang kedudukan akal dan wahyu dalam penyelidikan berteraskan Islam. Dalam penyelidikan lazim Sains Kemasyarakatan, hanya akal menjadi sandaran untuk dalil dan sumber teori ilmu (epistemologi). Penyelidikan lazim ini menolak wahyu. Dalam Islam, disepakati bahawa wahyu mestilah diletakkan sebagai dalil dan sumber teori ilmu (epistemologi) yang utama mengatasi akal. Justeru, bagaimanakah kedudukan wahyu dan akal dalam penyelidikan berkaitan Islam? Bagi menjawab persoalan ini, ilmu mantik digunakan sebagai rujukan. Ilmu mantik merupakan ilmu yang menyusun berkenaan kaedah penaakulan dalam Islam. Mantik juga ada menyusun kaedah pendalilan yang boleh digunakan dalam berhujjah. Persoalannya apakah kedudukan akal dalam penyelidikan berteraskan Islam? Bagaimanakah kaedah penyelidikan Islam menyusun kedudukan akal dan wahyu dalam penyelidikan Islam? Bagi menjawab persoalan ini, kertas kerja ini akan menggunakan kajian perpustakaan dan analisis tekstual untuk menganalisis kedudukan wahyu dan akal menurut ilmu mantik. Makalah ini akan melihat definisi akal dan wahyu dalam Islam. Kemudian dianalisis kedudukan akal dan wahyu dalam perbincangan ilmu mantik untuk diguna pakai sebagai kaedah dalam penyelidikan berteraskan Islam. Mantik dilihat dapat merungkaikan kekeliruan antara kedudukan akal dengan wahyu dalam penyelidikan. Begitu juga dibincangkan bagaimanakah wahyu boleh digunakan dalam menjalankan penyelidikan berkaitan Islam menurut kaedah penyelidikan Islam. Hasil kajian ini mendapati bahawa ilmu mantik ada mengiktiraf dalil naqli dan dalil aqli. Akal sebenarnya mendapat pengiktirafan dalam Islam tetapi tidak melebihi kedudukan wahyu. Sebaliknya, wahyu memainkan peranan yang penting dalam menjalankan penyelidikan berkaitan Islam. Namun dalam menggunakannya terdapat kaedah yang tertentu dalam menggunakan wahyu tersebut.
\end{abstract}

Kata Kunci: Kaedah penyelidikan islam; penghujahan; akal; wahyu; Al-Qur'an; mantik

(C) 2017 Penerbit UTM Press. All rights reserved

\subsection{PENDAHULUAN}

Makalah ini secara umumnya ingin melihat kedudukan wahyu dan akal dalam penyelidikan berteraskan Islam. Secara khususnya, kajian ini melihat bagaimana ilmu mantik menyusun kedudukan wahyu dan akal dalam susunan penghujahan. Susunan kedudukan wahyu dan akal dalam ilmu mantik perlu dilihat kerana susunan dalam ilmu mantik oleh itu boleh dijadikan asas kepada susunan wahyu dan akal dalam penyelidikan berteraskan Islam

Secara lebih khusus, makalah ini akan membincangkan definisi akal dan definisi wahyu. Setelah itu, analisis dibuat ke atas kedudukan wahyu dan akal dalam susunan penghujahan ilmu mantik. Setelah mendapat gambaran berkenaan wahyu dan akal, barulah analisis dibuat dalam menyatakan kedudukan wahyu dan akal dalam penyelidikan. Oleh yang demikian, makalah ni akan menyentuh definisi akal, definisi wahyu, wahyu dan akal menurut ilmu mantik dan analisis kedudukan wahyu dan akal dalam penyelidikan. 


\title{
2.0 DEFINISI AKAL
}

Akal merupakan satu kemampuan yang dikurniakan khas untuk manusia. Menurut Ibnu Sina (1992), manusia mempunyai tujuh kemampuan iaitu makan, tumbuh, berkembang biak, pengamatan berkenaan hal-hal yang istimewa, pergerakan di bawah kekuasaan, mengetahui hal-hal yang umum, dan memiliki kehendak memilih yang bebas.

Tumbuh-tumbuhan hanya memiliki kemampuan untuk makan, tumbuh, berkembang biak. Haiwan pula memiliki untuk makan, tumbuh, berkembang biak, pengamatan berkenaan hal-hal yang istimewa dan bergerak di bawah kekuasaan. Manakala kemampuan mengetahui hal-hal yang umum, dan memiliki kehendak memilih yang bebas merupakan kurniaan khusus untuk manusia dan tidak dimiliki oleh makhluk ciptaan Allah selainnya. Akal membezakan antara manusia dengan tumbuhan dan haiwan. Malah akal juga menjadi alat untuk menentukan tahap kepintaran sesama manusia.

Akal selalunya dikaitkan dengan rasionaliti. Rasionaliti ialah apa-apa sahaja pendapat yang boleh diterima akal sebagai sumber kepada sesuatu pengetahuan atau sesuatu justifikasi (Lacey, 1996). Rasionaliti inilah yang selalu digunakan dalam sesuatu penyelidikan. Penyelidikan merupakan alat untuk memperoleh sumber pengetahuan yang sah dan boleh dipercayai iaitu sumber pengetahuan yang saintifik dan logik (Yan Piaw, 2006). Logik pula ialah sesuatu yang diterima akal. Oleh itu, sesuatu yang rasional ialah suatu ilmu atau justifikasi yang diberikan mestilah yang boleh diterima akal. Perkara ini dapat dilihat dengan lebih jelas pada takrifan akal mengikut tradisi barat. Akal menurut barat seperti yang disebutkan dalam Brittanica Encyclopedia (2012) ialah:

\begin{abstract}
"Akal dalam tradisi orang-orang Barat ialah sebuah fakulti yang melibatkan kesedaran, mengingat, mempertimbang, menilai dan menentukan sesuatu. Akal pada suatu sudut yang tertentu mencerminkan kejadian-kejadian berikut, iaitu sensasi, persepsi, emosi, memori, kehendak, hujah yang pelbagai jenis, tujuan, pilihan, ciri-ciri personaliti dan ketidaksedaran".
\end{abstract}

Daripada takrifan sebelum ini, dapat disimpulkan bahawa peranan akal terbahagi kepada tiga. Pertamanya mengkaji, menyelidik, menerima maklumat atau ilmu. Kedua, setelah diterima barulah maklumat itu dikumpul, diingat dan disimpan. Pada tahap ini akal berfungsi sebagai khazanah. Ketiga, mengeluarkan ilmu atau maklumat melalui komunikasi rasmi atau tidak.

Pada asasnya, Islam juga menerima tiga peranan akal seperti takrifan sebelum ini. Namun akal menurut barat sedikit berbeza dengan Islam. Barat hanya mengiktiraf akal sebagai sumber ilmu pengetahuan dari sudut zahir. Dalam Islam selain dari akal dalam takrifan barat dari sudut zahir, masih terdapat sumber lain iaitu sudut batin.

Dalam Islam akal tidak dilihat dari sudut zahir. Akal juga mempunyai sudut batinnya. Buktinya dapat dilihat daripada beberapa pengertian akal yang menonjolkan sisi batin akal seperti pengertian-pengertian berikut. Menurut al-Jurjani (2000), akal ialah jiwa yang diciptakan Allah SWT yang berhubungan dengan badan manusia. Ada juga yang mentakrifkan akal bererti cahaya (nur) dalam hati untuk mengetahui kebenaran dan kebaikan (Muhammad Taqiy al-Mudarrisi,1992). Al-Sa'diy (2008) pula menyatakan akal merupakan nur rohani yang diketahui darinya perkara-perkara dharuri dan nazhari. Menurut Mukhtar Yahya (1972), akal itu ialah suatu sifat daripada ciri-ciri jiwa (hati). Dengan adanya akal itu, jiwa dapat mengetahui dan mengenal sesuatu yang ma'qul (yang dapat difikir) dan mahsus (yang dapat dikesan oleh pancaindera).

Daripada pengertian-pengertian yang telah dibincangkan, dapat difahami bahawa akal merupakan cahaya (nur) dalam hati yang berguna untuk mengetahui kebenaran dan kebatilan, mengatur dan mengendalikan jasmani. Oleh itu, akal bukan hanya mempunyai kekuatan berfikir secara rasional tetapi akal mempunyai sisi rohani dan mengawal kekuatan berfikir secara rasional serta menentukan tahap tertinggi yang boleh dicapainya. Perkara ini dapat dilihat dengan lebih jelas sekiranya difahami berdasarkan ayat berikut:

"Dan sesungguhnya Kami jadikan untuk neraka jahanam, banyak dari jin dan manusia yang mempunyai hati, (tetapi) tidak mahu memahami dengannya (ayat-ayat Allah), dan yang mempunyai mata (tetapi) tidak mahu melihat dengannya (bukti keesaan Allah) dan yang mempunyai telinga (tetapi) tidak mahu mendengar dengannya (ajaran dan nasihat); mereka itu seperti binatang ternak, bahkan mereka lebih sesat lagi; mereka itulah orang-orang Yang lalai.” (Surah al-A'raf 7:179)

Ayat di atas menunjukkan bahawa setiap manusia dan jin mempunyai hati. Walaupun hati bukan organ untuk akal, namun hati sebenarnya pengimbang kepada fungsi akal. Sekalipun seseorang itu pintar berfikir, namun belum tentu dia akan dapat menggunakannya dengan betul untuk berfikir. Seseorang tetap memerlukan kesucian hati untuk menghasilkan keputusan yang tepat. Di sinilah peranan takwa untuk membersihkan hati dan menjadi petunjuk kepada akal. Sebab itulah dalam ayat sebelum ini dinyatakan dengan jelas mereka mempunyai hati tetapi tidak berfikir dengannya untuk memahami ayat-ayat Allah.

Dalam kata lain, menurut Islam hati juga mampu berfikir seperti tugas yang diberikan kepada akal menurut definisi barat. Namun Islam menambah, untuk menggunakan akal dengan betul, cahaya rohani diperlukan dan ia datang dari hati. Di sinilah perlunya akal dilihat dari dua sudut, zahir dan batin.

Perkara ini dikuatkan lagi dengan takrifan akal menurut al-Ghazali (2010). Beliau memberi empat penjelasan dalam mentakrifkan akal. Pertama, akal ialah sesuatu sifat yang boleh membezakan antara manusia dengan haiwan dan makhluk lain. Melalui anugerah akal, manusia mampu dan dapat menerima segala ilmu yang berbentuk teori serta mampu untuk menyusun idea-idea. Akal dalam bentuk ini merupakan asas utama dan pokok kepada fikiran manusia. Kedua, akal ialah segala ilmu dan pengetahuan yang dapat memastikan sesuatu kemungkinan terhadap perkara-perkara yang mungkin dan kemustahilan terhadap perkara yang berbentuk mustahil.

Ketiga, akal ialah segala ilmuwan dan pengetahuan yang diperoleh oleh manusia melalui pengalaman-pengalaman yang lalu dan apa yang dialaminya. Hal tersebut berdasarkan kebiasaan orang yang berpengalaman atau mempunyai pengalaman itu adalah terdiri daripada mereka yang berakal. Sebaliknya, orang tidak mempunyai pengalaman itu dikira orang yang jahil dan bodoh. Keempat, akal ialah sesuatu yang mempunyai kekuatan atau sesuatu kekuatan yang diperoleh atau dicapai ekoran perkembangan daripada kemuncak naluri tersebut. Akal mampu dan dapat mengenal serta mengesan akibat-akibat daripada segala perbuatan atau mengenal segala perkara. Lantaran itu apabila kekuatan untuk mengawal dan membendung nafsu tersebut tercapai, maka seseorang itu dikira orang yang berakal. Jika difahami daripada takrifan al-Ghazali (2010), tiga takrifan pertama boleh dikatakan sebagai akal dari zahirnya dan takrifan akal yang keempat menunjukkan yang akal mempunyai sudut batinnya. 
Kesimpulannya akal ialah suatu naluri, tabiat dan hakikat semula jadi yang ada pada manusia. Melalui hakikat dan naluri tersebutlah manusia itu mampu dan bersedia untuk memahami dan menerima segala ilmu pengetahuan yang diajar. Akal boleh di ibarat dan diumpamakan cahaya atau nur yang dicampakkan dalam hati manusia, dengan nur itu mereka mendapat sesuatu atau juga untuk mendapat petunjuk (al-Muhasibi, 1971). Akal menurut pengertian Islam bukanlah semata-mata akal yang boleh menyelesaikan masalah-masalah ilmiah tetapi juga lebih daripada itu ialah akal yang boleh menimbangkan antara perkara yang baik dengan yang buruk, antara yang benar dengan yang palsu dan akal itu tunduk pula kepada wahyu Ilahi.

Namun al-Muhasibi (1971) juga menyatakan akal mempunyai kemampuan yang terhad dan mempunyai kelemahan. Kelemahan akal manusia ialah tidak dapat mencapai hakikat tentang Allah. Ia bukanlah merupakan sesuatu kecacatan. Namun kelemahan akal itu untuk menunjukkan ia ada batasnya dan sebagai pembatasan terhadap tugasnya. Abdul Halim Mahmud (1995) menegaskan akal tidak mampu untuk memikirkan perkara-perkara akidah, prinsip-prinsip akhlak dan perundangan serta kaedah-kaedah hukum sesama manusia. Apabila tiba pada tiga perkara tersebut, akal tidak dapat memahaminya kerana perkara-perkara berkaitan akidah banyak melibatkan perkara-perkara yang ghaib. Akal tidak tahu dan tidak dapat memahaminya secara bersendirian. Begitu juga dan perkara berkaitan prinsip-prinsip akidah dan perundangan. Akal tidak dapat menentukan dengan konsisten dan sama yang manakah yang baik dan manakah yang buruk. Di sinilah datangnya peranan wahyu sebagai pemandu kepada akal.

\title{
3.0 DEFINISI WAHYU
}

Wahyu ialah pemberitahuan daripada Allah kepada salah seorang Nabi dari Nabi-Nabi-Nya tentang sesuatu perkara dengan salah satu cara dari cara-cara (Nuh al-Faqir, 2003). Wahyu di sini merupakan pemberitahuan tentang sesuatu perkara dari Allah kepada seorang Nabi daripada Nabi-nabiNya. Antara cara-cara wahyu disampaikan kepada Nabi-nabiNya ialah mimpi yang benar, perbualan secara langsung di sebalik hijab, datang suara seperti bunyi loceng atau kawanan lebah dan datang malaikat membawa wahyu dengan berupa sebagai manusia (Manna' Qattan, 1998).

Al-Quran diturunkan sebagai petunjuk dan hidayah bagi umat Islam. Al-Quran menjawab beberapa persoalan bagi membimbing akal untuk diyakini dan diamalkan. Antaranya seperti perkara-perkara ghaib, akidah, ketuhanan, hari akhirat. Begitu juga persoalan akhlak, bagaimana hendak menjadi baik dan apakah kelebihannya. Al-Quran juga mengandungi persoalan perundangan yang mampu memberi kedamaian kepada masyarakat (Abdul Halim Mahmud, 1995). Wahyu merupakan sumber rujukan tertinggi dalam Islam. Firman Allah SWT :

\begin{abstract}
"Sesungguhnya telah datang kepada kamu cahaya kebenaran (Nabi Muhammad) dari Allah, dan sebuah Kitab (Al-Quran) yang jelas nyata keterangannya. Dengan (Al-Quran) itu Allah menunjukkan jalan-jalan keselamatan serta kesejahteraan kepada sesiapa yang mengikut keredaanNya, dan (dengannya) Tuhan keluarkan mereka dari gelap-gelita (kufur) kepada cahaya (iman) yang terang-benderang, Dengan izinNya; dan (dengannya juga) Tuhan menunjukkan mereka ke jalan Yang lurus." (Surah al-Maidah 5:15-16)
\end{abstract}

Dalam ayat tadi Allah SWT dengan jelas menyatakan bahawa al-Quran merupakan petunjuk dan harus diikuti bagi sesiapa yang mahukan keselamatan di dunia mahu pun di akhirat. Namun pada masa yang sama, al-Quran tidak akan dapat difahami tanpa penerangan dan contoh yang praktikal. Penerangan dan contoh praktikal yang dimaksudkan ialah al-Sunnah.

Al-Sunnah ialah segala yang lahir atau berupa perkataan, perbuatan atau taqrir yang disandarkan kepada Nabi SAW. Walaupun alSunnah lahir dari Nabi SAW dan disandarkan kepada Nabi SAW, ia juga merupakan wahyu. Hal ini jelas dengan firman Allah SWT berdasarkan ayat berikut:

"Dan Dia (Muhammad) tidak memperkatakan (sesuatu yang berhubung dengan agama Islam) menurut kemahuan dan pendapatnya sendiri. Segala yang diperkatakannya itu (sama ada Al-Quran atau al-Sunnah) tidak lain hanyalah wahyu yang diwahyukan kepadanya" (Surah al-Najm 53: 3-4).

Ayat di atas menjelaskan bahawa segala apa yang datang dari Nabi SAW adalah wahyu. Tidak ada satu perkara pun yang datang dari Nabi adalah bukan wahyu. Sebab itulah segala apa yang disandarkan kepada Nabi SAW sama ada dari perkataan, perbuatan atau taqrir merupakan al-Sunnah dan merupakan salah satu bentuk dari wahyu secara tidak langsung.

Daripada definisi al-Sunnah dan ayat al-Quran itu dapat dikatakan bahawa yang menetapkan hukum adalah Allah SWT walaupun sesuatu perkara itu pada zahirnya datang dari Nabi SAW. al-Sunnah merupakan salah satu kaedah dalam menzahirkan hukum Allah SWT atau sebagai dalil, penerangan dan penunjuk ke atas hukum Allah SWT.

Menurut Ibrahim Abd al-Rahman Ibrahim (1999), sekurang-kurangnya terdapat enam tugas al-Sunnah. Pertama, mendatangkan hukum baru yang tidak ada dalam al-Quran sama ada dengan lafaz yang qat'ie atau zhonni. Kedua, memperkuatkan hukum yang telah ada dalam al-Quran. Ketiga, menerangkan hukum yang telah didatangkan oleh al-Quran sebagai tafsir, penghuraian atau pun penerangan. Keempat, al-Sunnah juga boleh menasakhkan hukum yang ada dalam al-Quran. Kelima, al-Sunnah juga boleh menasakhkan hukum yang ada dalam al-Sunnah sebelumnya. Keenam al-Sunnah boleh menjadi asas kepada hukum yang tidak ada dalam al-Quran.

Dalam kata lain al-Sunnah juga merupakan wahyu daripada Allah SWT sama seperti al-Quran. Namun al-Quran tetap mempunyai banyak keistimewaan kerana Al-Quran adalah wahyu yang matlu, yang lafaz dan maknanya daripada Allah SWT. Dengan membacanya sahaja sudah dijadikan sebagai ibadat. Lafaz dan kandungannya dijadikan sebagai mukjizat yang membuktikan kerasulan Muhammad SAW. al-Sunnah pula hanya maknanya sahaja daripada Allah SWT, sedangkan lafaznya daripada Nabi SAW sendiri.

Dari segi kedudukan, martabat al-Sunnah sama dengan martabat al-Quran kerana kedua-duanya adalah sama, iaitu wahyu daripada Allah SWT. Kelebihan al-Quran dalam perkara-perkara yang disebutkan, tidak berkait dengan masalah kehujjahan. Seandainya al-Quran tidak mempunyai kelebihan-kelebihan tersebut, maka ia tetap merupakan hujjah selama ia merupakan wahyu daripada Allah SWT. Sama halnya seperti kitab-kitab samawi terdahulu.

Perkara ini dapat dilihat dengan jelas sekiranya melihat kepada pembahagian dalam menasakhkan hukum. Terdapat empat jenis dalam menasakhkan hukum. Pertama, Menasakhkan al-Quran dengan al-Quran. Kedua menasakhkan al-Quran dengan al-Sunnah. Ketiga, 
menasakhkan al-Sunnah dengan al-Quran dan keempat menasakhkan al-Sunnah dengan al-Sunnah dengan yang lain (Manna' al-Qattan, 1998). Jenis-jenis menasakhkan hukum ini menunjukkan al-Quran dan al-Sunnah boleh menggantikan satu dengan yang lainnya.

Sebab itulah wahyu juga dikenali sebagai dalil naqli. Dalil naqli ialah dalil yang diambil terus daripada al-Quran dan al-Sunnah (H. Syukriadi Sambas, 2003). Ia dikenali sebagai naqli kerana ia menjalani proses pemindahan, sama seperti maksudnya secara bahasa iaitu pindah. Dalil naqli hanyalah memindahkan dalil dari al-Quran dan al-Sunnah. Percaya kepada al-Quran termasuk dalam keimanan kepada kitab. Percaya kepada al-sunnah merupakan manifestasi kepada keimanan kepada Rasulullah SAW. Oleh sebab ia termasuk dalam rukun Iman, maka tidak dibenarkan sebarang keraguan kepadanya.

Hal ini akan menjadi lebih jelas jika melihat kepada sumber ilmu dalam ilmu akidah. Ilmu akidah ialah ilmu yang membicarakan tentang perkara yang ghaib dan ketuhanan. Dalam membincangkan ilmu akidah, terdapat tiga sumber yang boleh mendatangkan ilmu. Pertama pancaindera yang baik. Kedua, wahyu. Ketiga, akal (al-Sa'diy, 2008). Ini menunjukkan dalam mencapai ilmu dalam Islam wahyu haruslah dirujuk dan pada masa yang sama Islam juga mengiktiraf peranan akal dan pancaindera. Namun bagaimanakah Islam menyusun kedudukan akal dan wahyu dalam penyelidikan? Perkara ini akan dijelaskan dalam bahagian yang berikut.

\subsection{WAHYU DAN AKAL MENURUT ILMU MANTIK}

Daripada perbincangan di atas, dapat di fahami bahawa dalam menjalankan penyelidikan berkaitan Islam, wahyu haruslah dijadikan rujukan utama. Namun pada masa yang sama, akal dan pancaindera turut memainkan peranan yang penting. Persoalannya bagaimanakah susunan akal dan wahyu dalam menjalankan penyelidikan?

Untuk menyelesaikan perkara ini, ilmu mantik dirujuk. Menurut Abu Abdullah Muhammad Ahmad Muhammad `Ulaisyi (1877), ilmu mantik adalah ilmu tatanan berfikir yang dapat memelihara otak dari kesalahan berfikir dengan pertolongan Allah SWT. Al-Jurjani (2000) pula mendefinisikan ilmu mantik sebagai suatu alat yang mengatur kerja otak dalam berfikir agar terhindar daripada kesalahan selain merupakan ilmu kecermatan praktis. Al-Quasini (t.t) pula mendefinisikan ilmu mantik sebagai ilmu yang membahas objek-objek pengetahuan tasawur (worldview) dan tasdiq (proposisi) untuk mencapai interaksi dari keduanya atau suatu pemahaman yang dapat mendeskripsikan tasawur dan tasdiq.

Takrifan ilmu mantik bukanlah menjadi tumpuan utama perbincangan makalah ini. Namun dalam ilmu mantik, terdapat satu bahagian yang dinamakan pembahagian hujah. Dalam bahagian ini membincangkan berkenaan suatu alasan yang menunjukkan kebenaran sesuatu perkara. Menurut ilmu mantik hujah boleh dibahagikan kepada dua iaitu naqli dan aqli. Hujah naqli ialah hujah yang diambil daripada alQuran dan al-Sunnah (Ahmad Damanhuri, 2006). Manakala hujah aqli ialah hujah yang diambil dari pemikiran akal. Pembahagian ini merupakan pembahagian yang jelas. Ia membezakan antara hujah yang diambil daripada wahyu dan hujah yang didapati dari akal dan pancaindera.

Hujah naqli kemudiannya dibahagikan kepada al-Quran dan al-Sunnah iaitu sumber utama wahyu itu sendiri. Namun begitu ada juga yang memasukkan ijmak dan qiyas sebagai dalil naqli kerana dengan syarat ijmak dan qiyas tersebut merujuk terus kepada al-Quran dan al-Sunnah. Hujah aqli pula merupakan perbincangan yang sedikit panjang (Ahmad Damanhuri, 2006). Di bawah hujah aqli terdapat lima sumber iaitu hujah burhan, hujah jadal, hujah khitobah, hujah sya ' $r$ dan hujah sufastah (al-Shanqiti, 2007).

Pertama, hujah aqli burhan ialah qiyas yang tersusun dari premis-premis yang kebenarannya telah terbukti (H. Syukriadi Sambas, 2003). Hujah aqli burhan akan dijelaskan dengan lebih mendalam dibawah nanti kerana antara lima sumber hujah aqli, hujah burhan merupakan hujah yang mencapai darjat yakin dan mempunyai enam cara untuk mendapatkan hujah aqli burhan. Enam cara untuk mendapatkan hujah aqli burhan ialah auliyyat, musyahadah, mujarrobat, mutawatirat, hadsiyyat dan mahsusat. (Ahmad Damanhuri, 2006).

Kedua, hujah aqli jadal ialah qiyas yang tersusun dari premis-premis masyhur yang berbeza kerana perbezaan waktu dan tempat atau kelompok sehingga premis itu dianggap benar menurut orang yang tertentu dan yang beradu alasan. Tujuan hujah aqli jadal ialah untuk memaksa lawan dan memberikan kepuasan kepada orang yang sempit pengetahuannya dengan alasan yang diterima (al-Shanqiti, 2007).

Ketiga, hujah aqli khitobah pula ialah qiyas yang tersusun dari premis-premis yang diterima akal yang lahir dari sesuatu yang diyakini. Khitobah sebenarnya dapat merangsang manusia dengan sesuatu yang bermanfaat bagi mereka sebagaimana yang dilakukan oleh penceramah (Ahmad Damanhuri, 2006).

Keempat, sya ' $r$ juga diiktiraf ilmu mantik sebagai sumber dalam penghujahan. Hujah aqli sya' $r$ ialah qiyas yang tersusun dari premispremis yang dapat membangkitkan semangat dan kesenangan jiwa dan meluluhkannya. Sya' $r$ diiktiraf sebagai sumber yang mempengaruhi jiwa dengan cara memberikan sesuatu yang menggembirakan dan sesuatu yang menakutkan supaya pengaruh-pengaruh tersebut akan lebih kuat jika menggunakan lirik-lirik syair atau suara yang merdu. Sebenarnya memang sya ' $r$ dimanfaatkan dalam pengajian ilmu klasik. Boleh dikatakan setiap ilmu Islam disusun dalam bait syair yang indah seperti al-Sullam al-Munawwaraq dalam ilmu mantik, manzumah al-Baiquniyyah dalam ilmu ulum hadis dan banyak lagi (al-Shanqiti, 2007).

Kelima, hujah aqli sufastoh. Ia merupakan qiyas yang tersusun dari premis-premis yang berupa rekaan dan bohongan. Hujah aqli ini sebenarnya bukan untuk digunakan kerana tidak membawa faedah. Ia adalah untuk dikenali supaya dapat dielakkan kecuali digunakan apabila terdapat pihak yang tidak mahu mendengar kebenaran. Hujah yang salah ini digunakan sebagai balasan kepada hujah mereka yang tidak benar (Ahmad Damanhuri, 2006).

Berbalik kepada hujah burhan yang disebutkan tadi. Hujah burhan pula terdiri dari enam sumber yang membawa kepada penemuan yang yakin. Pertama, Auliyyat iaitu hujah yang secara rasional kebenarannya dan tidak memerlukan sesuatu yang lain, baik berbentuk tekaan atau pun eksperimen dan sebagainya (al-Shanqiti, 2007). Kedua, Musyahadat. Musyahadat ialah hujah yang kebenarannya ditetapkan dengan pancaindera. Baik yang lahir atau yang batin. Musyahadah juga kadang kala dikenali sebagai Wujdaniyyat. Namun Wujdaniyyat biasanya dikaitkan dengan hujah yang kebenarannya diketahui melalui indera batin (intuisi) (Ahmad Damanhuri, 2006).

Ketiga, Mujarrabat. Mujarrobat merupakan hujah yang secara rasional kebenarannya yang memerlukan sesuatu yang lain, baik berupa tekaan atau eksperiman dan sebagainya (H. Syukriadi Sambas, 2003). Keempat, mutawatir. Mutawatir ialah hujah yang ditetapkan melalui berita dari banyak orang, yang tidak mungkin mereka bersepakat dalam mendustakannya kerana banyaknya dan dari orang yang dipercayai (Ahmad Damanhuri, 2006). Kelima hadsiyyat. Hadsiyat ialah hujah secara rasional yang penetapan hukumnya tidak memerlukan 
pemerhatian yang berulang-ulang (al-Shanqiti, 2007). Keenam Mahsusat. Mahsusat ialah apa yang dapat diketahui melalui pancaindera yang lima iaitu pendengaran, penglihatan, bau, rasa dan sentuhan (Ahmad Damanhuri, 2006).

Pembahagian hujah menurut ilmu mantik seperti yang dibincangkan tadi dapat di gambarkan seperti Rajah 1:

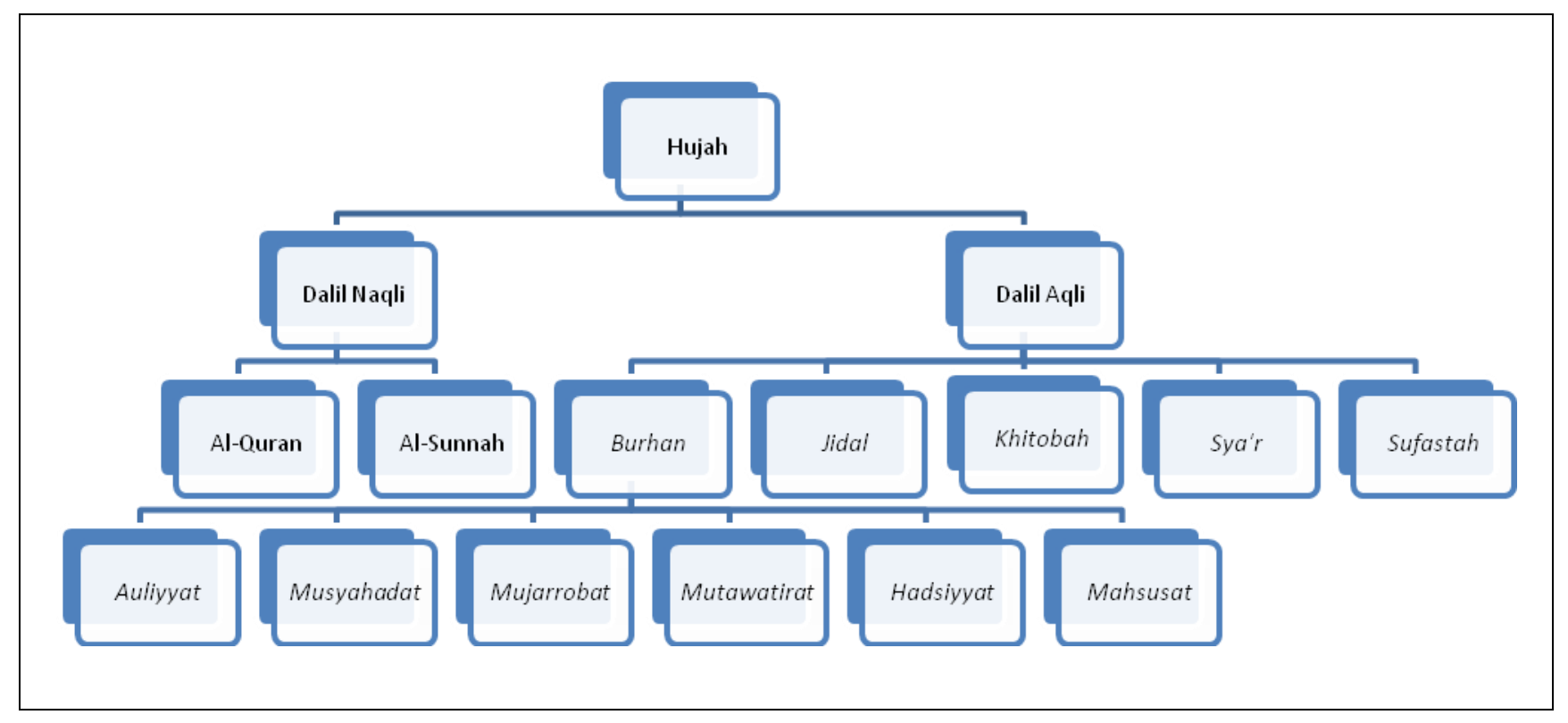

Rajah 1 Pembahagian hujah menurut ilmu mantik

Rajah 1 menunjukkan bahawa hujah dalam ilmu mantik terdiri daripada dua sumber utama iaitu naqli dan aqli. Dalil naqli boleh didapati daripada al-Quran dan al-Sunnah. Dalil aqli pula bersumber daripada Burhan (Kebenaran), Jidal (Perbahasan), Khitobah (Ceramah), Sya'r (Perasaan) dan Sufastah (Khayalan). Manakala Dalil Burhan pula terdiri dari enam perkara. Auliyyat (Aksioma), Musyahadat (Empirikal), Mujarrobat (Eksperimen), Mutawatirat (Periwayatan), Hadsiyyat (Dugaan/Hipotesis) dan Mahsusat (Intuisi). Penghujahan dalam Islam, terbahagi kepada dua. Pertama naqli, kedua aqli. Dalil naqli sebagai wahyu merupakan dalil yang utama berbanding dalil-dalil aqli. Apa-apa sahaja yang bersandarkan kepada akal tidak dapat melebihi dalil-dalil naqli.

Dalil aqli pula terbahagi kepada lima, Burhan (Kebenaran), Jidal (Perbahasan), Khitobah (Ceramah), Sya'r (Perasaan) dan Sufastah (Khayalan). Keutamaannya adalah mengikut susunan. Burhan merupakan sumber yang akan menghasilkan ilmu yang diyakini (Ahmad Damanhuri, 2006). Selepas itulah barulah, Khitobah, Sya'r dan Sufastah. Bagi dalil Burhan, susunan kedudukan pendalilan adalah pertama, Auliyyat, kedua, Musyahadat, ketiga, Mujarrobat, keempat, Mutawatirat, kelima Hadsiyyat dan keenam Mahsusat.

Sebelum analisis secara lebih mendalam terhadap kedudukan wahyu dan akal dalam penyelidikan, suka diingatkan bahawa kajian yang dilakukan disiplin Sains Kemasyarakatan adalah berdasarkan logik (Blaikie, 2009), terhad kepada apa-apa yang dapat dilihat oleh panca indera yang lima (Reevany Bustami, Eleesya Nasruddin \& Norman Blaikie, 2006) dan apa yang dibuktikan melalui kajian atau eksperimen (Yan Piaw, 2006).

Jika sesebuah penyelidikan berkaitan Islam dilakukan, bagaimanakah dengan perkara-perkara yang diwahyukan melalui al-Quran dan al-sunnah? Bagaimanakah perkara-perkara ghaib dan sam iyyat dapat dikesan oleh panca indera yang lima? Sedangkan dinamakan sam 'iyyat adalah kerana terdapat hal-hal yang hanya dapat didengar melalui wahyu dan tidak dapat dilihat oleh panca indera seperti syurga, neraka, malaikat dan sebagainya (Al-Sa'diy, 2008). Selain itu, bagaimanakah sekiranya hal yang diberitakan oleh al-Quran dan alsunnah tidak logik dan tidak masuk akal?

Oleh yang demikian, Muhammad Syukri Salleh (2008) mencadangkan perlunya kaedah penyelidikan Islam dibina bagi menjalankan penyelidikan berkaitan Islam dan orang Islam. Di sinilah perlunya kaedah penyelidikan Islam yang mempunyai tasawur dan epistemologi Islam bagi mengkaji berkenaan Islam dan orang Islam itu sendiri.

Untuk hal yang demikian, ilmu mantik sekurang-kurangnya dapat membantu untuk menyusun kedudukan wahyu dan akal dalam penyelidikan sebagai satu permulaan. Sebagaimana yang telah dibincangkan sebelum ini, ilmu mantik mempunyai bab yang khas dalam menyusun pembahagian dalil-dalil dan hujah yang diguna pakai.

Jika dianalisis, kaedah penyelidikan lazim, hanya berlingkar disekitar dalil aqli burhan. Itu pun tidak menggunakan kesemua pembahagian yang ada dalam dalil burhan tersebut. Mereka hanya mengiktiraf Auliyyat (Aksioma), Mujarrobat (Eksperimen), Hadsiyyat (Dugaan/Hipotesis) dan Mahsusat (Intuisi). Mutawatirat (Periwayatan), dan Musyahadat (Empirikal) tidak diterima dalam penyelidikan lazim. Malah yang lebih merbahaya, tiada tempat untuk wahyu iaitu al-Quran dan al-sunnah.

Maka boleh dikatakan bahawa kaedah penyelidikan Islam mempunyai ruang lingkup yang lebih luas daripada kaedah penyelidikan lazim walau pun hanya mengambil kira dalil naqli dan dalil aqli burhan. 


\subsection{ANALISIS KEDUDUKAN WAHYU DAN AKAL DALAM PENYELIDIKAN}

Sekiranya kaedah penyelidikan Islam ingin menggunakan dalil naqli dan dalil naqli burhan bagi menyusun kedudukan wahyu dan akal dalam penyelidikan, kedudukan wahyu dan akal perlulah dalam keadaan yang berikut.

Pertama, keenam-enam dalil aqli burhan yang digunakan secara dasarnya boleh diterima selagi mana tidak menyalahi dalil naqli iaitu wahyu. Ini bermakna, wahyu merupakan rujukan utama dalam kaedah penyelidikan Islam.

Kedua, dalil aqli burhan yang tidak disebut oleh wahyu adalah dibenarkan untuk dijadikan teori semasa dan perlu kajian lanjut. Dengan syarat selagi mana tidak bertentangan dengan wahyu. Pada masa yang sama, dalil aqli burhan boleh dibantu oleh dalil aqli. Hal ini menjadikan ruang lingkup kaedah penyelidikan Islam lebih luas kerana dibantu oleh wahyu iaitu dalil naqli.

Ketiga, dalil aqli burhan boleh digunakan untuk menerangkan, menyokong atau merasionalkan wahyu. Namun dalil aqli burhan tetap akan kekal sebagai dalil aqli burhan dan boleh disanggah oleh dalil yang setaraf dengannya. Hanya dalil naqli yang mempunyai imuniti dan tidak boleh disanggah. Ini bermakna, sebarang kajian yang dilakukan untuk menyanggah dalil aqli burhan yang menyokong dalil naqli, adalah menyanggah dalil aqli burhan tersebut dan bukannya menyanggah dalil naqli.

Akhirnya, yang keempat ialah dalil naqli perlu diterima dan diikut dalam penyelidikan dan perundangan Islam sama ada ia boleh dirasionalkan atau tidak.

\subsection{KESIMPULAN}

Sebagai kesimpulan, sekurang-kurangnya dapat disimpulkan lima perkara. Pertama, Islam mendefinisikan akal secara lebih holistik iaitu dari sudut zahir dan dari sudut batin. Kedua, akal diiktiraf sebagai sumber ilmu dalam Islam namun meletakkan had kepada kemampuan akal selaras dengan kelemahan akal yang tidak mampu memahami hakikat perkara ghaib. Ketiga, pembahagian hujah menurut ilmu mantik menyatakan dengan jelas kedudukan wahyu dan akal dalam penghujahan. Keempat, selaras dengan definisi akal dari sudut akal menurut Islam yang juga mengiktiraf dari sudut batin, pembahagian hujah aqli burhan mengiktiraf wujdaniyyat (Intuisi). Selain itu, Islam juga mengiktiraf mutawatirat (Periwayatan), Pembahagian ini menunjukkan Islam mempunyai jawapan yang lebih holistik dalam memahami akal dan mengiktirafnya. Kelima dalil naqli dan dalil aqli burhan boleh dimanfaatkan dalam penyelidikan berkaitan Islam. Wahyu dan akal boleh saling sokong menyokong namun sekurang-kurangnya terdapat empat perkara perlu diberi perhatian seperti yang telah dibincangkan di atas.

Dengan itu mantik dilihat dapat merungkaikan kekeliruan antara kedudukan akal dan wahyu dalam penyelidikan. Kedudukan akal mendapat pengiktirafan dalam Islam tetapi tidak melebihi kedudukan wahyu. Begitu juga kedudukan akal dan wahyu ditentukan dengan jelas melalui ilmu

\section{Penghargaan}

Makalah ini merupakan sebahagian daripada hasil penyelidikan yang bertajuk Seni Penaakulan dalam Kaedah Penyelidikan Islam dan telah dibiayai oleh Geran Research University Individual (RUI), Universiti Sains Malaysia (2012-2016) [(RUI)1001/CISDEV/816207].

\section{Rujukan}

Al-Quranul Karim

Abu Abdullah Muhammad Ahmad Muhammad 'Ulaisy. (1877). Idhah Ibda' Hikmah al-Hakim Fi Bayan Bismillahi al-Rahman al-Rahim. Mesir: Matba'ah alWahbiah.

Al-Ghazali, Abu Hamid. (2010). Ihya al-Ulum al-Din. Beirut: Dar Sodir.

Al-Muhasibi, al-Harith Ibn Asad. (1971). Al-Aql Wa Fahmi al-Ouran. Beirut: Dar al-Fikr.

Al-Jurjani, Ali Muhammad al-Syarif. (2000). Al-Ta'rifat. Beirut: Dar al-Kutub al-'Ilmiyyah.

Al-Sa'diy, Abdul Malik Abdul Rahman. (2007). Syarh al-Nasafiyah Fi al-Aqidah al-Islamiyah. Amman: Matba'ah al-Azhar.

Al-Shanqiti, Muhammad Bin Mahfuz Bin Mukhtar Fal. (2007). Al-Dhau al-Musyriq Ala Sullam al-Mantiq. Beirut: Dar al-Kutub al-Ilmiyyah.

Al-Quasini, Hassan Darwish. (t.t). Syarh 'Ala Matn al-Sullam Fi al-Mantik. Rabat: Maktabah Dar al-Iman.

Abdul Halim Mahmud. (1995). Islam dan Akal. Kuala Lumpur: Dewan Bahasa dan Pustaka.

Abdul Rahman Hj Abdullah. (2005). Wacana Falsafah Ilmu. Kuala Lumpur: Utusan Publications \& Distributors Sdn Bhd.

Abdul Rahman Hj Abdullah. (2007). Falsafah Dan Kaedah Pemikiran. Kuala Lumpur: Utusan Publications \& Distributors Sdn Bhd.

Ahmad Damanhuri. (2006). Idah al-Mubham Fi al-Ma'ani al-Sullam. Beirut: Maktabah al-Ma'arif.

Blaikie, Norman (2009). Designing Social Research. Cambridge: Polity Press.

H. Syukriadi Sambas. (2003). Mantik Kaidah Berpikir Islami. Bandung: PT Remaja Rosdakarya.

Ibnu Sina. (1992). Al-Najat Fi al-Mantiq Wa al-Ilahiyyat. Beirut: Dar al-Jil Li al Nashr Wa al-Tauzi'.

Ibrahim Abd al-Rahman Ibrahim. (1999). Al-Madkhal Lidirasah al-Fiqh al-Islamiy. Jarsh: Dar al-Thaqofah.

Lacey, A.R. (1996). A Dictionary of Philosophy. London: Routledge.

Manna' Qattan. (1998). Mabahith Fi 'Ulum al-Qur'an. Beirut: Muassasah al-Risalah.

Manna' Qattan. (1987). Mabahith Fi 'Ulum al-Hadith. Kaherah: Maktabah Wahbah.

Mat Rofa Ismail. (1997). Mantik Dalam Babak Pemikiran Ilmiah Tamadun Manusia. Kuala Lumpur: Dewan Bahasa dan Pustaka.

Muhammad Syukri Salleh. (1986). Beberapa Aspek Kesepaduan Ilmu Dalam Islam: Kes Ilmu Pembangunan Berteraskan Islam, Pendidikan Sepadu, Kumpulan Kertas Kerja 8 Universiti Kebangsaan Malaysia, Penerbit Universiti Kebangsaan Malaysia. hlm. 48-61.

Muhammad Syukri Salleh. (2008). "Kaedah Penyelidikan Berteraskan Islam: Keperluan, Kedudukan dan Hala Tuju”. Pemikir, Bil. 54, Oktober-Disember. hlm. 133164. Diterbitkan Semula Dalam Siri Kertas ISDEV No. 8.

Muhammad Taqiy al-Mudarrisi. (1992). Al-Mantiq al-Islami: Usuluhu Wa Manahijuhu. Kaherah: Dar al-Bayan Li al-Tiba'ah Wa al-Nashr.

Mukhtar Yahya. (1972). Pertumbuhan Akal dan Memanfaatkan Naluri Kanak-Kanak. Jakarta: Bulan Bintang.

Neuman, W. Lawarence (2006). Social Research Methods: Qualitative and Quantitative Approaches. Boston: Allyn and Bacon.

Nuh al-Faqir. (2003). Abaqa al-Raihan Fi Ulum al-Quran. Amman: Dar al-Isra' Li al-Nashr Wa al-Tauzi'.

Reevany Bustami, Eleesya Nasruddin \& Norman Blaikie. (2006). Lima Falsafah Penyelidikan. Pulau Pinang: KnowledgeCraftsmen. 
Yan Piaw, C. (2006). Kaedah dan Statistik Penyelidikan: Kaedah Penyelidikan. Malaysia: McGraw-Hill Education.

Yusuf al-Qardhawi. 1998. Al-Quran Berbicara Tentang Akal dan Ilmu Pengetahuan, terj. Abdul Hayyie al-Kattani, Irfan Salim \& sochimien MH. Jakarta: Gema Insani Press. 